\title{
Application of the Problem Based Learning Model to Communication Skills and Mathematical Problem Solving Skills in Junior High School Students
}

\author{
Khaerul Anam1, Raden Sudarwo ${ }^{2}$, Gunawan Wiradharma ${ }^{3}$ \\ 1,2,3 Mathematics Education, Universitas Terbuka, Indonesia \\ khaerul.anam@ecampus.ut.ac.id, sudarwo@ecampus.ut.ac.id, \\ gunawan.wiradharma@ecampus.ut.ac.id
}

\begin{abstract}
\section{Article History:}

Received : 02-07-2020

Revised 1 : 23-07-2020

Revised 2 : 17-09-2020

Accepted : 18-09-2020

Online : 03-10-2020

\section{Keywords:}

Mathematical

Communication;

Mathematical Problem-

solving;

Problem-Based Learning

This study aims to find out: (1) the influence of the use of the Problem-Based Learning (PBL) model on the mathematical communication skill; (2) the influence of the use of the Problem-Based Learning (PBL) model on the mathematical problem-solving skill. This study was conducted on class VIII. The research design is pre-post quasi experimental design. Samples were selected using the cluster random sampling technique. The employed instrument in this study was an essay test. The obtained data were then analyzed using independent samples t-test and simple linear regression. The results indicated that (1) the average score of students' mathematical communication skills taught by problem-based learning models was higher than those taught by conventional methods; (2) the average score of students' mathematical problem-solving abilities taught by problem-based learning models is higher than students taught by conventional methods;
\end{abstract}




\section{A. INTRODUCTION}

Mathematics or simply 'math' is one of the compulsory subjects given at the primary education level, i.e. the elementary school and the junior high school. According to Utami and Wutsqa, mathematics is one of the subjects that students must study at every level of education (Utami \& Wutsqa, 2017). The importance of mathematics is not only learned in the classroom, but mathematics is close to daily activities. To make students understand to mathematic, the development of mathematic curriculum according to National Council of Teachers of Mathematics, (2000) in schools is directed at five general objectives, i.e. The five objectives are: a) students learn to respect math; b) students build their confidence in the ability to use math; c) students become problem solvers; d) students learn mathematical communication, and e) students learn mathematical reasoning. Ozturk \& Guven, (2016) state that problem-solving is the scientific process of a person who goes through a phase of understanding a problem to then look for the information needed to decide on the solution and evaluate the solution. Maimunah et al (2016) defined problem-solving as an intellectual activity to find solutions by involving knowledge and experience. Problem-solving is the ability to use previous knowledge in new situations to solve a problem (Ulya, 2016). From the description above, it can be concluded that mathematical problem-solving ability is the effort or effort of a person to solve mathematical problems faced by using methods, procedures, steps, and strategies that can be accounted for mathematically. Mathematical communication is a way for students to express and interpret mathematical ideas orally or in writing, either in the form of pictures, tables, diagrams, formulas, or demonstrations (Prayitno, Sudi; St Suwarsono, 2013). The mathematical communication skill is the students' ability to convey mathematical ideas both orally and in writing (Hadi \& Novaliyosi, 2019). In this study, researchers will use written mathematical communication. Based on some of the opinions above, it can be concluded that written mathematical communication is students' ability to use vocabulary, notation, structure, mathematics in the form of reasoning, linkages, or connections, and problem-solving to provide certain information to one another.

Teacher-oriented learning is still a tradition that continues today other than that the mathematics learning process in the field to date refers to the short-term needs, namely for being able to solve the questions given by the teacher at the end of the learning process, daily or semester exams, final school exams, and national exams. Mathematics subject has not been directed to meet long-term needs. Currently, students are only directed to be able to use mathematical formulas without understanding when and how the lesson is applied in everyday life (Soraya et al., 2018). This reflects that the learning process has been not optimal yet in which, in the end, it makes students' mathematical communication skills and mathematical problem-solving skills still low. According to Hikmah, a reality that occurs in the learning process is that when students are given a problem or a question to solve, most students cannot solve the problem properly (Hikmah, 2017). At present, there are still many complaints both from students' parents and mathematics education experts concerning the low ability of students in the use of mathematics, especially the use in daily life (Tusiran, 2015).

Some studies explain that the results of the mathhematics learning process in schools have not shown satisfactory results. This condition is shown by the results of the evaluation from The Third International Mathematics and Science Study that, from the three times implementation of TIMSS 2007, 2011, and 2015, the achievements of Indonesian students in mathematics are always in the bottom position with an average score that is quite far below the international average score in overall results and detailed results divided in each dominant content and cognitive (Hadi \& Novaliyosi, 2019). In general, the results of the three times implementation of TIMSS indicated that Indonesian students have a basic knowledge of mathematics, especially in the Number and Data domains. However, they had problems in the 
Algebra and Geometry. The following is a table of question characteristics with the 2011 TIMSS Difficulty Index

Table 1. Characteristics of questions with the Difficulty Index TIMSS 2011

(Hadi \& Novaliyosi, 2019)

\begin{tabular}{|c|c|c|c|}
\hline Content Domain & Topic & Cognitive Domain & Correct Answer \\
\hline \multirow{2}{*}{ Numbers } & Fractions & Application & $9 \%$ \\
\cline { 2 - 4 } & Decimal & Knowledge & $8 \%$ \\
\hline \multirow{2}{*}{ Algebra } & Equation and Inequalities & Reasoning & $18 \%$ \\
\cline { 2 - 4 } & Equation and Inequalities & Application & $1 \%$ \\
\cline { 2 - 4 } & Measurement & Application & $25 \%$ \\
\hline \multirow{2}{*}{$\begin{array}{c}\text { Data and } \\
\text { Opportunities }\end{array}$} & Geometry Shapes & Reasoning & $0 \%$ \\
\cline { 2 - 4 } & Opportunity & Application & $25 \%$ \\
\hline
\end{tabular}

Taken together, it can be concluded that our students still have difficulty applying their knowledge in problem-solving. According to Leung and Puji, the data from TIMSS showed that the mathematics learning process in Indonesia is more emphasized on the mastery of basic skills. The low scores achieved in the national evaluation of math indicated that the quality of understanding concepts in students' mathematical problem-solving and students' mathematical communication is still relatively low. Therefore, math education becomes one of the main focuses in improving the educational process.

Along with the low ability of students' mathematical communication skills and students' mathematical problem-solving skills, the researcher presumes that this is inseparable from the learning system applied in schools. One of them is the use of inappropriate learning models, approaches, strategies, or methods. According to Annajmi, Learning in schools is currently still dominated by teachers as key informant (Annajmi, 2012). The use of improper teaching methods can affect the low of students' learning outcomes on the mathemathic subject, especially in mathematical skills, i.e. problem-solving skills, reasoning skills, communication skills, representation skills, and mathematical connection skills. The factor that leads to the lack of students' ability in math is because the learning process is emphasized on the practice of working on questions routinely (widely known as drilling activity) and does not involve student activities (Hasratuddin, 2010). These learning conditions produce students who lack awareness, are less creative, and are less independent. This means that teachers should use learning models that are activating students to participate, experimentalbased, encouraging students' ability to produce work, or problem-based. The problem-based learning (PBL) model can provide a significant influence on problem-solving skills in science subjects (Ferreira \& Trudel, 2012). The use of the PBL is effective in the learning process to improve students' problem-solving skills (Kadir et al., 2016). Furthermore, a study concerning the PBL model has a positive and significant effect on communication skills and mathematical problem-solving (Kodariyati \& Astuti, 2016).

The problem-based learning model is one of the learning model alternatives that can greatly provide hope for improving the quality of education (Ahmadi \& Khoiru, 2010). The PBL is a student-centered learning process focusing on problems that must be solved by students through small group division (Sukmawati, 2019). Gallow stated that PBL encourages students to be active in discussion activities and solve problems given (Asyari et al., 2016). Steps in the problem-based learning process help students improve their critical thinking skills (Masek \& Yamin, 2011). Problem-based learning begins with presenting a real problem to students. From this problem, it is hoped that students can easily obtain concepts from the results of the inquiry. Torp and Sage also put forward the definition of problem-based learning, namely problem-based learning is focused, experimental learning organized around 
the investigation, and resolution of messy, real-world problems (Wynn \& Okie, 2017). The steps of the PBL according to Polya are (1) understanding the problem, (2) devising a plan, (3) carrying out the plan, and (4) reviewing the steps of solution (Polya, 1973). The advantages of the PBL include (a) making students easier to understand the learning process, (b) giving students challenges and satisfaction, (c) increase the learning activities, (d) making students understand the problems of daily life, (e) developing students' knowledge, (f) helping students understand the nature of learning, (g) creating a pleasant learning environment, and (h) stimulating students to learn on an ongoing basis (Wulandari \& Surjono, 2013).

Several studies have proven the success of this problem-based learning model in improving students' mathematical abilities both mathematical communication skills and mathematical problem-solving skills. A study conducted by Etherington, (2011) indicated that the PBL is superior compared to traditional learnin. Furthermore, a study conducted by Kodariyati \& Astuti, (2016) showed that learning models have a positive and significant effect on students' communication skills and students' mathematical problem-solving skills. A study conducted by Nurbiati et al, (2016) indicated that the PBL model can improve students' mathematical communication skills. Based on the description above, it can be considered that the PBL model can be used as an effort to improve students' mathematical communication skills and students' mathematical problem-solving skills. Therefore, this study is carried out to find out the influence of the use of the Problem-Based Learning model on the mathematical communication skill and the mathematical problem-solving skill of students of public MTsN in Lombok Tengah.

Based on the background above, the research question in this study is "How is the influence of the use of the Problem-Based Learning (PBL) model on the mathematical communication skill and the mathematical problem-solving skill of students of public MTs in Lombok Tengah?". From the formulation of the research question above, this study aims to (1) examine the mathematical communication skill of students who learned with the PBL model whether it is better than that of students who learned with the conventional methods, (2) examine the mathematical problem-solving skill of students who learned with the PBL model whether it is better than that of students who learned with the conventional methods.

\section{B. METHODS}

The type of this study was a quantitative study with pre-post test quasi experimental design with control group. This quasi-experimental approach was conducted to compare the influence of different treatments, i.e. the experiment class and the control class. The applied research design was a pretest-posttest control group design. This research design can be seen in the figure below.

\begin{tabular}{|llll|}
\hline PBL Module & $\mathbf{O}_{1}$ & $X$ & $\mathbf{0}_{1}$ \\
Conventional & $\mathbf{O}_{2}$ & & $\mathbf{O}_{2}$ \\
\hline
\end{tabular}

Figure 1. Design pre-post test quasi experimental (Sugiyono, 2012)

Where: $\mathrm{Q}_{1}$ : Pretest in the experiment class, $\mathrm{Q}_{2}$ : Posttest in the experiment class, $\mathrm{X}$ : The treatment, i.e. the PBL model, for the experiment class

The pretest was conducted by giving a test in the form of an essay on the material of TwoVariable Linear Equation Systems totalling 9 questions. The question consists of 6 items which are questions of mathematical communication skills and three questions to measure the ability to solve mathematical problems. The pretest aims to see the mathematical skills of 
students before being given the treatment and then the posttest to see the students' mathematic abilities after being given the PBL model treatment.

This study involved two classes consisting of one experimental class and one control class and selected randomly, namely the first group as the experiment class in which the group would be given treatment in the form of learning with a problem-based learning model carried out by the class teacher, while the second group as a control class in which the group was given treatment with a conventional model (there was no application of the PBL model by the classroom teacher). Both groups were given a pretest to see the initial ability of communication and problem solving before being given treatment, then given a posttest to determine the effect and differences of students' communication skills and problem-solving skills between the group that was given treatment with the problem-based learning model and the control group with the conventional learning model.

Mathematical communication skills test indicators used in this study are: (1) (Drawing) the students' ability to express mathematical situations or ideas in the form of pictures, diagrams, or graphs; (2) (Mathematical expressions) the ability to describe conditions, drawings, diagrams or real objects into language, symbols, ideas, or mathematical models; (3) (Written texts) include the ability of students to state daily events in language or mathematical symbols correctly, the ability to compose arguments or express opinions and provide written explanations for the answers given. The problem-solving indicators used in this research are the steps to solve the pattern problem in the context of (1) solving problems that arise in mathematics; (2) solving problems in the context of everyday life; (3) applying various strategies to solve the problem. The learning material raised in this study is the Twovariable Linear Equation System (SPLDV). The number of instruments for mathematical communication skills six essay items, and tools for measuring students' mathematical problem-solving abilities are three essay items.

The population in this study were all Class VIII MTSN students who were in the Central Lombok district from April to May in the 2016/2017 academic year. The sample used in this study was determined using a simple random sampling technique, which is a sampling method where each member of the population is given the same opportunity to be selected as a sample (Arieska and Hediani, 2018). Furthermore, students of class VIII MTS Negeri 1 Lombok Tengah were selected with an average of 35 students per class.

The data collected were data on communication skills and data on mathematical problem management abilities obtained from the test results given to students. Before the test was given to the students, the instrument validity was tested using the product-moment formula, and the reliability test was carried out using the Cronbach Alpha formula. Data processing was carried out by using the normality test using the Lilliefors test and the homogeneity test using the Fisher Test. Hypothesis testing used t-test and simple linear regression with the help of SPSS and Microsoft Excel software.

\section{RESULT AND DISCUSSION}

\section{Result}

In the Table 2, in the experiment class, students' mathematical communication skills increased from an average of 35.86 to 81.14. Furthermore, students' mathematical problemsolving skills also increased from an average of 22.91 to 70.17 . The data indicated that there was an increase in both mathematical communication skills and mathematical problemsolving skills on students after being given the treatment using the problem-based learning (PBL) model. 
Table 2. Data of Pretest-Posttest on the Communication Skill and the Problem-solving Skill in the Experiment Class

\begin{tabular}{ccccc}
\hline \multirow{3}{*}{ Score } & \multicolumn{4}{c}{ Eksperiment } \\
\cline { 2 - 5 } & \multicolumn{2}{c}{$\begin{array}{c}\text { Mathematical } \\
\text { Communication Skills }\end{array}$} & Mathematical Problem-solving \\
& Pre & Post & Pre & Post \\
\cline { 2 - 5 } & 35.86 & 81.14 & 22.91 & 70.17 \\
Average & 60 & 100 & 40 & 90 \\
Max & 15 & 50 & 10 & 54 \\
Min & 9.03 & 9.78 & 9.29 & 8.7 \\
SD & 100 & 100 & 100 & 100 \\
Ideal & 100 & & & \\
\hline
\end{tabular}

Table 3. Data of Pretest-Posttest on the Communication Skill and the Problem-solving Skill in the Control Class

\begin{tabular}{|c|c|c|c|c|}
\hline \multirow{3}{*}{ Score } & \multicolumn{4}{|c|}{ Control } \\
\hline & \multicolumn{2}{|c|}{$\begin{array}{c}\text { Mathematical } \\
\text { Communication Skills }\end{array}$} & \multicolumn{2}{|c|}{$\begin{array}{c}\text { Mathematical Problem } \\
\text { Solving Skills }\end{array}$} \\
\hline & Pre & Post & Pre & Post \\
\hline Average & 34 & 74.86 & 21.89 & 65.11 \\
\hline Max & 50 & 95 & 42 & 85 \\
\hline Min & 15 & 50 & 10 & 48 \\
\hline SD & 7.65 & 10.18 & 7.85 & 9.54 \\
\hline Ideal & 100 & 100 & 100 & 100 \\
\hline
\end{tabular}

Based on the Table 3, in the control class, students' mathematical communication skills increased from an average of 34 to 74.86. Furthermore, students' mathematical problemsolving skills also increased from an average of 22.89 to 65.11 . The data indicated that there was an increase in both mathematical communication skills and mathematical problemsolving skills for students.

The normality test on communication skills and problem-solving skills was conducted by using the Lilliefors test. The results of the normality test can be seen in the Table 4 below.

Table 4. Normality Test for the Experiment Class and the Control Class

\begin{tabular}{ccccc}
\hline & \multicolumn{4}{c}{ Mathematic Skills } \\
\cline { 2 - 5 } Test & \multicolumn{3}{c}{ Mathematical } & \multicolumn{2}{c}{ Mathematical Problem } \\
Communication Skills & \multicolumn{2}{c}{ Solving Skills } \\
\cline { 2 - 5 } & pretest & Posttest & pretest & posttest \\
\hline$t_{\text {hit }}$ & 0,115 & 0,139 & \multicolumn{3}{c}{0,075} & 0,061 \\
$t_{\text {tab }}$ & & \multicolumn{4}{c}{0,150} & \\
\hline Explanations & & \multicolumn{3}{c}{ Normal } \\
\hline
\end{tabular}

Based on the Table 4, it can be concluded that the data of the mathematical communication skill and the mathematical problem-solving skill of students from the experiment class and the control class was normally distributed.

The homogeneity test on communication skills and problem-solving skills was conducted by using the F test (Fisher's test). The results of the homogeneity test can be seen in the Table 5 below. 
Table 5. Homogeneity Test on Data of the Communication Skill and the Problem-solving Skill

\begin{tabular}{|c|c|c|c|c|}
\hline \multirow[b]{3}{*}{ Test } & \multicolumn{4}{|c|}{ Mathematical Skills } \\
\hline & \multicolumn{2}{|c|}{$\begin{array}{c}\text { Mathematical } \\
\text { Communication Skills }\end{array}$} & \multicolumn{2}{|c|}{$\begin{array}{c}\text { Mathematical Problem } \\
\text { Solving Skills }\end{array}$} \\
\hline & pretest & posttest & pretest & posttest \\
\hline $\mathrm{F}_{\text {hit }}$ & 1,39 & 1,15 & 1,40 & 1,07 \\
\hline $\mathrm{F}_{\mathrm{tab}}$ & \multicolumn{4}{|c|}{1,77} \\
\hline Explanation & \multicolumn{4}{|c|}{ Homogen } \\
\hline
\end{tabular}

Based on the Table 5, it can be concluded that the data of the mathematical communication skill and the mathematical problem-solving skill of students from the experiment class and the control class was homogeneous.

Next, the first hypothesis in this study is that the mathematical communication skill of students who learned with the problem-based learning model is higher than that of students who learned with the conventional methods.

Table 6. Hypothesis Testing for the Influence of the Use of the Problem-Based Learning Model on Students' Mathematical Communication Skill

\begin{tabular}{cc}
\hline \multirow{2}{*}{ Result } & Eksperiment-Control \\
\cline { 2 - 2 } & Posttest Mathematical Communication Skills \\
\hline $\mathrm{t}_{\text {hit }}$ & 2,634 \\
\hline $\mathrm{t}_{\mathrm{tab}}$ & 2,030 \\
\hline $\mathrm{Df}$ & 68 \\
\hline Sig. & 0,010 \\
\hline Explanation & there are difference \\
\hline
\end{tabular}

Based on Table 6, obtained from the calculation of the results of the posttest students' mathematical communication skills using the help of SPSS software, the following data were obtained, it is found out that the $t_{\text {count }}$ is greater than $t_{\text {table }}(2.634>2.030)$ meaning that the null hypothesis $\left(\mathrm{H}_{0}\right)$ is rejected while the alternative hypothesis $\left(\mathrm{H}_{\mathrm{a}}\right)$ is accepted. This means that the average mathematical communication skill of students who learned with the problem-based learning model is higher than that of students who learned with the conventional methods. Therefore, it can be concluded that the mathematical communication skill of students who learned with the problem-based learning model is higher than that of students who learned with the conventional methods among grade VIII students throughout junior high schools in Lombok Tengah.

The second hypothesis in this study is that the mathematical problem-solving skill of students who learned with the problem-based learning model is higher than that of students who learned with the conventional methods.

Table 7. Hypothesis Testing for the Influence of the Use of the Problem-Based Learning Model on Students' Mathematical Problem-solving Skill

\begin{tabular}{cc}
\hline Result & $\begin{array}{c}\text { Eksperiment-Control } \\
\text { Post-test Mathematical Problem Solving Skills }\end{array}$ \\
\hline $\mathrm{t}_{\mathrm{hit}}$ & 2,315 \\
\hline $\mathrm{t}_{\mathrm{tab}}$ & 2,030 \\
\hline $\mathrm{Df}$ & 68 \\
\hline Sig. & 0,024 \\
\hline Explanation & there are difference \\
\hline
\end{tabular}


Based on Table 7, obtained from the calculation of the results of the posttest students' mathematical problem-solving skills using the help of SPSS software, the following data were obtained, it is found out that the $t_{\text {count }}$ is greater than $t_{\text {table }}(2.315>2.030)$ meaning that the null hypothesis $\left(\mathrm{H}_{0}\right)$ is rejected while the alternative hypothesis $\left(\mathrm{H}_{\mathrm{a}}\right)$ is accepted. This means that the average mathematical problem-solving skill of students who learned with the problem-based learning model is higher than that of students who learned with the conventional methods. Therefore, it can be concluded that the mathematical problem-solving skill of students who learned with the problem-based learning model is higher than that of students who learned with the conventional methods.

\section{Discussion}

a. The Influence of Problem-Based Learning (PBL) Model on The Mathematical Communication Skill.

Based on the results of calculations on descriptive analysis and hypothesis testing using the independent sample t-test, it can prove that the PBL model can have a positive and significant effect on students' mathematical communication skills, namely the average mathematical communication skills of students who learn with the PBL learning model are higher when compared with students who learn with conventional learning. The ability of mathematical communication in the experimental class has increased higher when compared to the control class. This can happen because the class that applies the PBL model in the mathematics learning process, especially in the two-variable linear equation system material, looks more enthusiastic about learning. Problem Based Learning is an innovative learning model that can provide active learning conditions for students. This model is used by the teacher in teaching a subject matter related to the essential competencies he chooses by giving problems to students to solve. Giving problems that must be resolved is only as a tool or media for students to carry out learning activities. In other words, the process of teaching and learning activities takes place in order to solve or solve existing contextual problems.

There are five stages of the PBL model in learning, namely student orientation to problems, organizing students to learn, guiding group investigations, developing and presenting work results, and analyzing and evaluating the problem-solving process. From the five stages in the PBL model, aspects of mathematical communication can be developed. In learning using PBL, there is a process of working together with one another or discussion in small groups. It is reflected in the fourth stage at the PBL stage, namely in the process of guiding individual or group investigations. With this discussion process taking place, there is an interaction between students and between students and teachers. This interaction creates a process of brainstorming in the form of ideas, ideas, statements, assumptions about the problem, answers, and also results in a message transfer process. The message that is transferred is in the form of mathematical material learned in class. The interaction that occurs in students is called communication, both oral and written.

In the realm of group discussions, students completing worksheets containing questions on contextual problems is one way to develop students' mathematical communication skills because answering them requires explanations and reasoning and not just final answers from standard procedures, with student problem questions. practice to develop communication skills through reading problems and understanding them, then communicating mathematical ideas into writing so that they can be understood by others. The next stage is presenting the work in front of the class. Presentation activities can train students to dare to speak in front of others and can develop their verbal communication skills to explain the results of discussions and respond to the work of other groups. In addition, mathematics communication skills are 
also developed in the form of questions at the beginning of the lesson. For example, students are asked to name and write examples of two-variable linear equations through the given authentic problems. This is what makes students' mathematical communication skills formed through the application of the PBL model in the learning process. In other words, students understand mathematical concepts through their mathematical communication skills. This is in accordance with what is stated by (NCTM, 2000) that: "Communication is an essential part of mathematics and mathematics education. It is a way of sharing ideas and clarifying understanding. Through communication, ideas become objects of reflection, refinement, discussion, and amendment. The communication process also helps build meaning and permanence for ideas and makes them public. When students are challenged to think and reason about mathematics and to communicate the results of their thinking to others orally or in writing, they learn to be clear and convincing"

Communication plays an essential role in learning mathematics because mathematics is not only a thinking tool that helps students to develop patterns, solve problems and draw conclusions but also as a tool to communicate thoughts, ideas and ideas in a clear, precise and concise manner. With communication, students can exchange and express their ideas both to other students and to the teacher. Through communication, ideas can become communication materials in a discussion, reflection, and evaluation of student understanding. Several studies have shown that PBL can improve students' mathematical communication skills because the experimental group provides better mathematical communication skills and shows more vital teamwork.

While the class that applies conventional model learning. Based on observations, more mathematical concepts are given through teacher lecture activities. Exercise questions are done after students listen to the explanation from the teacher. Students do not find their mathematical concepts. This makes students less understanding of mathematical symbols because the mathematical concepts obtained by memorization and in the form of direct examples from the teacher. Therefore, the mathematical communication skills of students who get learning with the PBL model are higher than students who get conventional learning.

b. The Influence of Problem-Based Learning (PBL) Model on the Mathematical ProblemSolving Skill.

Based on the results of calculations on descriptive analysis and hypothesis testing using the independent sample t-test, it can prove that the PBL model can have a positive and significant effect on students' mathematical problem-solving abilities. This calculation is also supported by the results of empirical observations made at each meeting. In a classroom that uses the PBL model, students do not fully receive the information provided by the teacher, but students are active in seeking information about the material they are learning. In the PBL model, students learn based on problems. Students find the concepts they learn through solving the problems they find, so that students are trained to find solving steps independently. This is in accordance with the statement (Handika \& Wangid, 2013) that problem-based learning is a learning model that emphasizes solving problems or problems as a starting point or basis in the learning process. In addition, through group discussion activities, students are asked to find their own mathematical concepts. This discussion activity is an effective way to train students to find steps for solving independently based on a given problem. Teachers do not only transfer knowledge to students but students must use or utilize their initial abilities to be able to find new concepts. Peer interaction and peer learning are effective tools for learning, and are good motivators. In learning with the PBL model, the teacher's role is as a facilitator to guide the course of group discussions. At the end of the learning process, 
the teacher gives description questions to be done independently. Students not only write down the answers to the questions, but students are asked to write down the steps to solve them. By using these steps, students' mathematical problem-solving abilities can be developed. This means that through the application of the PBL model in learning, students can improve their problem-solving skills based on the problems given.

\section{CONCLUSION AND SUGGESTIONS}

The results of this study are to provide input to teachers in improving skills and problemsolving in mathematics learning at the elementary school level through the problem-based learning (PBL) model. The results of this study indicate that the use of the PBL model can improve communication skills and problem-solving in mathematics learning at the elementary level. However, the effect is not very good. Future research can use learning media or other models, such as inquiry, discovery, and project-based learning in improving mathematics learning skills.

Based on the results and discussion, it can be concluded that (1) mathematical communication skill of students who learned with the problem-based learning model is higher than that of students who learned with the conventional methods; (2) mathematical problem-solving skill of students who learned with the problem-based learning model is higher than that of students who learned with the conventional methods; and (3) there is a positive relationship between the mathematical communication skill and the mathematical problem-solving skill.

\section{ACKNOWLEDGEMENT}

Our gratitude goes to the Supervisor who has helped and supported the implementation of this research and also thanks to the teachers, schools, and students who have provided information and facilitated related to the research that I did.

\section{REFERENCES}

Ahmadi, S. A., \& Khoiru, I. (2010). Proses Pembelajaran Inovatif dan Kreatif Dalam Kelas. Jakarta Pustakaraya.

Annajmi, A. (2012). No Title Peningkatan Kemampuan Pemahaman Konsep Matematik Siswa Smp Melalui Metode Penemuan Terbimbing Berbantuan Software Geogebra. MES, 2(1), 1-10.

Arieska, P. K. dan N. H. (2018). Pemilihan Teknik Sampling Berdasarkan Perhitungan Efisiensi Relatif. Jurnal Statistika, 6(2), 166-171.

Asyari, M., Al Muhdhar, M. H. I., Susilo, H., \& Ibrohim, I. (2016). Improving critical thinking skills through the integration of problem based learning and group investigation. International Journal for Lesson and Learning Studies, 5(1), 36-44. https://doi.org/10.1108/IJLLS-10-2014-0042

Dkk, N. (2016). Pengaruh Pendekatan Problem Based Learning Terhadap Kemampuan Komunikasi Matematis Dan Motivasi Belajar Siswa. Jurnal Pena Ilmiah, Vol. 1, No, 1001. https://ejournal.upi.edu/index.php/penailmiah/article/view/3015/pdf

Etherington, M. (2011). Investigative primary science: A problem-based learning approach. Australian Journal of Teacher Education, 36(9), 36-57. https://doi.org/10.14221/ajte.2011v36n10.1

Ferreira, M., \& Trudel, A. (2012). Tje Impsct of Problem Based Learning (PBL) on Student Attitudes Toward Science, Problem-Solving Skills, and Sense of Community in the Classroom. Journal of Classroom Interaction, 47(1), 23-30.

Hadi, S., \& Novaliyosi. (2019). TIMSS Indonesia (Trends in International Mathematics and Science Study). Prosiding Seminar Nasional \& Call For Papers Program Studi Magister Pendidikan Matematika Universitas Siliwangi, 562-569.

Handika, I., \& Wangid, M. N. (2013). Pengaruh Pembelajaran Berbasis Masalah Terhadap Penguasaan Konsep Dan Keterampilan Proses Sains Siswa Kelas V. Jurnal Prima Edukasia, 1(1), 85-93. https://doi.org/10.21831/jpe.v1i1.2320

Hasratuddin. (2010). Meningkatkan Kemampuan Berpikir Kritis dan Kecerdasan Emosional Siswa SMP 
Melalui Pendekatan Matematika Realistik. Disertasi Tidak Terbit: Universitas Pendidikan Indonesia (UPI).

Hikmah, H. (2017). Pengembangan Perangkat Pembelajaran Matematika Realistik pada Siswa Kelas V SD. Jurnal Saintefik, 3(1), 24-30.

Kadir, Z. A., Abdullah, N. H., Anthony, E., Salleh, B. M., \& Kamarulzaman, R. (2016). Does Problem-Based Learning Improve Problem Solving Skills?-A Study among Business Undergraduates at Malaysian Premier Technical University. International Education Studies, 9(5), 166-172. https://doi.org/10.5539/ies.v9n5p166

Kodariyati, L., \& Astuti, B. (2016). Pengaruh Model Pbl Terhadap Kemampuan Komunikasi Dan Pemecahan Masalah Matematika Siswa Kelas V SD. Jurnal Prima Edukasia, 4(1), 93-106. https://doi.org/10.21831/jpe.v4i1.7713

Maimunah, M., Purwanto, P., Sa'dijah, C., \& Sisworo, S. (2016). Penerapan Model Pembelajaran Matematika Melalui Pemecahan Masalah untuk Meningkatkan Penalaran Matematis Siswa Kelas X-A SMA Al-Muslimun. Jurnal Review Pembelajaran Matematika, 1(1), 17-30. https://doi.org/10.15642/jrpm.2016.1.1.17-30

Masek, A., \& Yamin, S. (2011). The effect of problem based learning on critical thinking ability: a theoretical and empirical review. International Review of Social Sciences and Humanities, 8(2), 1-8.

NCTM. (2000). Principles and Standards for School Mathematics Overview. In United States of America. The National Council of Teachers of Mathematics, Inc.

Ozturk, T., \& Guven, B. (2016). Evaluating students' beliefs in problem solving process: A case study. Eurasia Journal of Mathematics, Science and Technology Education, 12(2), 411-429. https://doi.org/10.12973/eurasia.2016.1208a

Polya, G. (1973). How To Solve It A New Aspect of Mathematical Method (Princeton, New Jersey: Princeton University Press. Princeton University Press.

Prayitno, Sudi; St Suwarsono, T. S. (2013). Identifikasi indikator kemampuan komunikasi matematis siswa dalam menyelesaikan soal matematika berjenjang pada tiap-tiap jenjangnya. Prosiding Konferensi Nasional Pendidikan Matematika V, 384-389.

Soraya, F., Yurniwati, Y., Cahyana, U., \& Syarif Sumantri, M. (2018). The Application of Realistic Mathematics Education (RME) Approach to Increase the Creative Thinking Ability of Fraction Subject Matter for Fourth-Graders of SDN Rawajati 06 Pagi. American Journal of Educational Research, 6(7), 1016-1020. https://doi.org/10.12691/education-6-7-19

Sugiyono. (2012). Metode Penelitian Kuantitatif, Kualitatif dan R \& D.Bandung:Alfabeta. In Metode Penelitian Kuantitatif, Kualitatif dan $R \quad \& \quad$ D.Bandung:Alfabeta. https://doi.org/10.1017/CB09781107415324.004

Sukmawati, R. \& H. S. (2019). Implementasi Pembelajaran Berbasis Masalah Untuk Meningkatkan Metakognisi Siswa Sma. Jurnal Chemistry in Education, 8(1), 1-6.

Tusiran. (2015). Peningkatan Kemampuan Pemecahan Masalah Matematika Dan Kemandirian Belajar Siswa Smp Dengan Menggunakan Pembelajaran Berbasis Masalah. Tesis Tidak Terbit: Universitas Negeri Makasar (UNM).

Ulya, H. (2016). Profil Kemampuan Pemecahan Masalah Siswa Bermotivasi Belajar Tinggi Berdasarkan Ideal Problem Solving. Jurnal Konseling Gusjigang, 2(1), 90-96. https://doi.org/10.24176/jkg.v2i1.561

Utami, R. W., \& Wutsqa, D. U. (2017). Analisis kemampuan pemecahan masalah matematika dan selfefficacy siswa SMP negeri di Kabupaten Ciamis. Jurnal Riset Pendidikan Matematika, 4(2), 166175. https://doi.org/10.21831/jrpm.v4i2.14897

Wulandari, B., \& Surjono, H. D. (2013). Pengaruh problem-based learning terhadap hasil belajar ditinjau dari motivasi belajar PLC di SMK. Jurnal Pendidikan Vokasi, 3(2), 178-191. https://doi.org/10.21831/jpv.v3i2.1600

Wynn, C. T., \& Okie, W. (2017). Problem-Based Learning and the Training of Secondary Social Studies Teachers: A Case Study of Candidate Perceptions during their Field Experience. International Journal for the Scholarship of Teaching and Learning, 11(2), 1-14. https://doi.org/10.20429/ijsotl.2017.110216 